\title{
AKAR DAN MOTIF FUNDAMENTALISME ISLAM: REFORMULASI TIPOLOGI FUNDAMENTALISME DAN PROSPEKNYA DI INDONESIA
}

\author{
Nunu Burhanuddin \\ Dosen Pemikiran Islam IAIN Bukittinggi \\ J1. Kubang Putiah, Kubang Putiah, Banuhampu, Kabupaten Agam, Sumatera Barat 26181, Indonesia. \\ Vice Direktur CIRES (Center for Information, Research and Empowerment Studies) Bukittinggi \\ Jl. Paninjauan Garergeh, Bukittinggi, Sumatera Barat. \\ E-mail: boer_n@yahoo.com
}

\begin{abstract}
:
Political movements and Islamic fundamentalism emerges to respond to internal and external challenges of modernity. Islamic world is also involved in this social upheaval to establish regional strategic meaning in economy and military toward the emerging European countries. In this context, Islamic fundamentalism is understood as the answer of certain social groups and political elites in the Islamic community in term of institutions, concepts and ideals that emerged in modern era. This paper aims to understand the meaning of Islamic fundamentalism in modern context together with its social confrontations, motives, goals and development. This paper shows that there are typology of Islamic fundamentalism in Indonesia, namely: First, fundamentalist group that emerged as a result of the struggles and conflicts of power in Indonesia as well as in The Middle Eastern countriest; second, fundamentalist group with a closed characteristics, who claimed that their group is right and others are wrong and even blasphemous. In addition, this group denied diversity and aimed of unification. Third, fundamentalist group that gain its influenced in particular Indonesian society like Hizb al-Tahrir of Indonesia.
\end{abstract}

Keywords:

Islamic fundamentalism; modernity; Indonesian context.

\begin{abstract}
Abstrak
Gerakan politik dan sistem pemikiran fundamentalisme Islam muncul untuk merespon tantangan-tantangan modernitas, baik internal maupun eksternal. Dunia Islampun terbawa arus pergolakan sosial seiring dengan upaya mereka dalam membentuk suatu wilayah yang memiliki makna strategis dalam bidang ekonomi, dan militer sebagai respon terhadap perkembangan negara-negara Eropa. Dalam konteks ini, fundamentalisme Islam dipahami sebagai jawaban dari kelompok sosial dan elit politik tertentu dalam komunitas Islam terhadap institusi, konsep-konsep dan cita-cita yang muncul dari dalam dunia modern. Tulisan ini berupaya memaknai fundamentalisme Islam dalam konteks pergumulan kemodernan. Suatu pergumulan yang menampakkan dirinya sebagai bagian integral dari sebuah konfrontasi sosial dengan segenap motif, tujuan dan arah perkembangannya. Setelah menelusuri akar dan motif kemunculan fundamentalisme, selanjutnya penulis membuat tipologi gerakan fundamentalisme serta prospeknya di Nusantara; pertama, Kelompok fundamentalisme yang lahir dari ketegangan, perebutan kekuasaan, hingga konflik yang ada di Timur Tengah; kedua, Kelompok fundamentalisme dengan ciri khas tertutup, merasa benar sendiri, gemar mengkafirkan, tidak mengakui keanekaragaman, dan menuntut penyeragaman; ketiga, Kelompok fundamentalisme lain yang cukup berpengaruh di ranah Nusantara seperti kelompok Hizb at-Tahrir Indonesia
\end{abstract}

Kata Kunci:

Fundamentalisme Islam; modernitas; konteks Indonesia.

DOI: http://dx.doi.org/10.15575/jw.v1i2.831

Received: September 2016 ; Accepted: November 2016 ; Published: November 2016

\section{A. PENDAHULUAN}

Fundamentalisme Islam merupakan sebuah ideologi yang berusaha untuk menetapkan kembali agama Islam sebagai suatu sistem politik dalam dunia modern. Islam menjadi suatu sistem organik total yang bersaing dalam jangkauan ideologi serta sistem negara lain. Dengan membuat term-term baru dan me- 
nafsirkan kembali konsep-konsep konvensional, fundamentalisme Islam menciptakan suatu paradigma baru yang terdiri dari unsurunsur teoritis dan empiris.

Sebagai sebuah gerakan politik dan sistem pemikiran, fundamentalisme Islam muncul untuk menanggapi tantangan-tantangan modernitas, baik internal maupun eksternal. Dalam hal ini, modernitas -yang diwakili oleh revolusi industri Prancis-- membawa suatu perubahan langsung atau tidak langsung terhadap evolusi manusia di seluruh dunia. Tak terkecuali dunia Islam yang ikut terbawa arus pergolakan sosial sejalan dengan upaya mereka dalam membentuk suatu rantai wilayah yang memiliki makna strategis, ekonomi, dan militer bagi negara-negara Eropa baru. Dalam konteks ini, fundamentalisme Islam dipahami sebagai jawaban dari kelompok sosial dan elit politik tertentu dalam komunitas Islam terhadap institusi, konsepkonsep dan cita-cita yang muncul dari dalam dunia modern.

Tulisan ini berupaya memaknai fundamentalisme Islam dalam konteks pergumulan kemodernan. Suatu pergumulan yang menampakkan dirinya sebagai bagian integral dari sebuah konfrontasi sosial dengan segenap motif, tujuan dan arah perkembangannya. Dari akar dan motif inilah fundamentalisme Islam yang masuk ke wilayah Nusantara dapat diposisikan menurut beberapa tipologi pergerakannya. Dari tipologi ini kita dapat membaca masa depan dan kemungkinan perkembangannya di ranah Nusantara.

\section{B. HASIL DAN PEMBAHASAN}

\section{Istilah Fundamentalisme}

Istilah fundamentalisme digunakan pertama kali untuk menyebut umat Kristen Penginjil Amerika, yang pada abad ke sembilan belas secara serius mengusahakan pemahaman harfiah dan menerapkan Bibel secara murni dan menolak teori Darwin yang populer saat itu. ${ }^{1}$ Kaum fundamentalis literalis dianggap

\footnotetext{
${ }^{1}$ Murad W. Hofmann, Menengok Kembali Islam Kita, trans. by Rahmani Astuti (Bandung: Pustaka Hidayah, 2002), 117.
}

naif, lantaran literalisme identik dengan cap primitif. Seiring berjalannya waktu, istilah fundamentalisme diberikan kepada para agamawan Protestan yang konservatif. Istilah ini kemudian dipublikasikan dalam pamflet yang berjudul "The Fundamentals of the faith" yang diterbitkan di Amerika pada tahun 1920an. Dalam pamflet tersebut kaum Protestan konservatif menjelaskan kembali bahwa kepercayaannya masih berlaku dan sesuai dengan kondisi sosial apapun. Keyakinan ini sekaligus sebagai bentuk perlawanan terhadap zaman liberal yang progresif. Dengan demikian, kemunculan fundamentalisme dimaksudkan untuk memerangi usaha menafsirkan kembali Bibel dan teologi dalam kerangka pengetahuan modern. ${ }^{2}$

Menurut Emarah, fundamentalisme adalah produk budaya Barat yang dipaksakan untuk diterapkan pada situasi-situasi khusus masyarakat muslim modern. Awalnya ia adalah gerakan Kristen Protestan Amerika pada abad 19 M yang lebih dikenal dengan sebutan Gerakan Millenium. Gerakan ini mengimani kembalinya Al-Masih secara fisik dan materi ke dunia, 1000 tahun sebelum datangnya hari kiamat. ${ }^{3}$ Lebih lanjut, kata Emarah, kemunculan mereka lebih disebabkan adanya penakwilan yang liberal atas teks Alkitab dan penolakan seutuhnya atas kehidupan sekular yang mewabah di Barat pada masa awal abad $19 \mathrm{M}$. Oleh karena itu mereka mengadakan seminar-seminar dan membentuk organisasiorganisasi untuk memprogandakan ajaranajarannya. Seperti pada tahun 1902 Organisasi Kitab Suci telah berhasil mempublikasikan 12 buku dengan judul "Fundamentals", sebagai pembelaan atas penafsiran Injil secara liberal serta menangkal kritik dan penakwilan atas kandungan Injil, dan pada tahun 1919 berdirilah Yayasan Fundamentalisme Kristen Interna-sional. Oleh karena itu, kata Emarah,

\footnotetext{
${ }^{2}$ Steve Bruce, Fundamentalisme, terj. Herbhayu Noerlambang (Jakarta: Erlangga, 2000), 15. Lihat juga, Ali Mudhofir, Kamus Teori dan Aliran Dalam Filsafat dan Teologi (Yogyakarta: Gajahmada University Press, 1996), 81.

${ }^{3}$ Muhammad Emarah, Fundamentalisme Dalam Perspektif Pemikiran Barat dan Islam (Jakarta: Gema Insani Press, 1990), 10.
} 
dalam sejarah Islam tidak dikenal istilah ini dan tidak tampak bersinggungan dengan gerakan fundamentalisme ini. ${ }^{4}$

Pendapat serupa dikemukakan oleh Karen Armstorng yang melihat istilah fundamentalisme sebagai istilah yang sesat. Di Islam sendiri istilah tersebut adalah Ușuliyah, kata yang merujuk pada penelitian atas sumbersumber berbagai aturan dan prinsip hukum Islam. ${ }^{5}$ Sebelumnya, Harun Nasution ${ }^{6}$ telah mengkritik penggunaan istilah fundamentalisme sebagai istilah yang tidak dikenal dalam Islam, apalagi jika dikaitkan dengan paham untuk kembali ke ajaran-ajaran lama dan menentang pembaruan, seperti dalam gerakan kaum Protestan yang muncul di Amerika itu.

Keberatan serupa disampaikan oleh Yusuf Qardhawi, ${ }^{7}$ bahwa istilah fundamentalisme merupakan istilah yang disodorkan oleh media Barat supaya diadopsi oleh kalangan umat manusia melalui media massa. Tetapi demikian, kata Yusuf Qardhawi, jika fundamentalisme dilabelkan kepada orang-orang yang berpegang kepada Islam secara benar dari segi akidah, syariah dan berbagai segi kehidupan, maka biarlah orang-orang yang keberatan itu menyebut kita sebagai fundamentalis. ${ }^{8}$

Lalu, siapa yang pertama kali mengintrodusir penggunaan istilah fundamentalisme untuk menamai sejumlah gerakan keagamaan kaum muslimin tersebut? Jawabannya adalah Leonard Binder, ${ }^{9}$ seorang Professor politik

\footnotetext{
${ }^{4}$ Emarah, Fundamentalisme Dalam Perspektif Pemikiran Barat dan Islam, 11.

${ }^{5}$ Karen Armstrong, Berperang Demi Tuhan (Bandung: Mizan, 2013), 17.

${ }^{6}$ Harun Nasution, Islam Rasional (Bandung: Mizan, 2000), 123.

${ }^{7}$ Yusuf Qardhawi, Masa Depan Fundamentalisme Islam (Jakarta: Pustaka Al-Kautsar, 1997), 15.

${ }^{8}$ Qardhawi, Masa Depan Fundamentalisme Islam, 21.

${ }^{9}$ Leonard Binder pernah menjadi Ketua Departemen Politik Science di UCLA dan University of Chicago. Beberapa buku karangan Binder antara lain Religion and Politics in Pakistan (1961), Iran: Political Development in a Changing Society (1962), The Ideological Revolution in the Middle East (1964), In a Moment of Enthusiasm: Political Power and the second Stratum in Egypt (1978), dan Islamic Liberalism (1988).
}

science dan direktur NEC (the Near East Center) di University of California, Los Angeles (UCLA) melalui bukunya "The Ideological revolution in The Middle East". Binder, memasukkan gerakan-gerakan di dunia muslim yang bertujuan membangun tatanan politik Islam dimana syariah diakui secara umum dan dijalankan berdasarkan hukum Islam. Suatu pelabelan yang menurut Ismail Raji Faruqi adalah suatu tindakan yang salah, sebab istilah yang benar untuk menamai gerakan kebangkitan kaum muslim itu adalah Nahdlah. ${ }^{10}$

Dengan demikian, sesungguhnya terdapat perbedaan yang jelas hingga secara diametral antara pemahaman dan pengertian istilah "fundamentalisme" seperti dikenal oleh Kristen Barat, dengan pemahaman istilah ini dalam warisan pemikiran Islam, baik masa lalu, modern, maupun kontemporer. Kaum 'fundamentalis' di Barat adalah orang-orang yang kaku, dan taklid yang memusuhi akal, metafor, takwil, dan qiyas, serta menarik diri dari masa kini dan membatasi diri pada penafsiran literal nash-nash. Sementara kaum "ușuliyyin̄" (bermakna fundamentalis) dalam peradaban Islam adalah para ulama ushul fikih yang merupakan kelompok ulama yang paling menonjol dalam memberikan sumbangsih dalam kajian-kajian akal atau ahli penyimpulan hukum, pengambilan dalil, ijtihad dan pembaruan. Dalam tulisan ini, penulis mendudukan istilah "fundamentalisme" ke arah gerakan yang mengusung pembaruan dengan ciri rasionalitas, penguatan praktik keagamaan hingga perlawanan terhadap hegemoni Barat, penjajahan dan kolonialisme.

\section{Akar dan Motif Lahirnya Fundamen- talisme}

\section{a. Akar Fundamentalisme Klasik}

Ada beberapa teori yang dapat menjelaskan tentang kemunculan fundamentalisme Islam, pertama akar historis fundamentalisme klasik, kedua, akar fundamentalisme modern, dan

\footnotetext{
${ }^{10}$ Lihat, Ismail Rajie Al-Faruqi, "Islamic Renaissance in Contemporary Society," Al Ittihad 15, no. 4 (1978): 15-23.
} 
ketiga, akar fundamentalisme post-modern. Akar fundamentalisme klasik dengan segala bentuknya lahir dari suatu proses sejarah yang panjang yang dapat ditemukan pada gerakan pemurnian yang diusung oleh Ibn Taimiyyah (1263-1328). ${ }^{11}$ Tema utama pemikiran Ibn Taymiyah adalah al-Ruju' ilā al-Qur'ān wa alSunnah, back to Quran and Sunnah. Dengan tekanan kepada pemurnian akidah, gerakan Ibn Taymiyah sering disebut gerakan muhyi athar al-salaf (menghidupkan kembali ajaran ulama salaf yang saleh), ${ }^{12}$ yakni praktek ajaran agama sebagaimana dilakukan oleh Rasulullah Saw., dan tiga generasi setelahnya, yaitu generasi para sahabat, tabiin dan tabiin-tabiin. Selain menghidupkan kembali ajaran salaf, pemikiran Ibn Taymiyah juga menjadi akar berkembangnya gerakan rasionalisme di dunia Islam, sekaligus menumbuhkan semangat perlawanan terhadap sistem-sistem di luar dasar-dasar Islam.

Gerakan pemurnian ${ }^{13}$ yang diusung oleh Ibn Taymiyah sejalan dengan pemikiran Imam

\footnotetext{
${ }^{11}$ Nama lengkapnya Taqiyudin Abul 'Abbas Ahmad bin Abdul Halim bin 'Abdussalam bin 'Abdullah bin Muhammad bin Taymiyyah al-Harrani al-Hanbali, dilahirkan di Haran. Untuk menyelamatkan dirinya dari serbuan bangsa Mongol, dia dibawa ke Damaskus tahun 1268 dan belajar ilmu agama kepada ayahnya, kemudian berguru kepada Al-Muqaddasi, Zainab binti Makki dan lain-lain. Meski ia menjadi pengikut mazhab Hanbali , tetapi tidak menghalangi dirinya untuk menjadi Mujtahid. Menurut Mar'i (penulis biografinya) pikiran-pikiran Ibn Taymiyyah banyak mempengaruhi Muhammad bin 'Abdul Wahab. Lihat, H.A.B Gibb dan J.H. Kramers, Shorter Encyclopedia of Islam (Leiden: E.J. Brill, 1974), 151-152.

${ }^{12}$ Konsep "menghidupkan ajaran ulama salaf" ini, kemudian menjadi ideal moral dan akar pemikiran gerakan-gerakan fundamentalisme Islam berikutnya dalam varian dan dinamikanya yang beragam. Baca, Husnul Qodim, "Dinamika Salafisme di Indonesia: Akar Intelektualitas dan Orientasi Ideologis yang Beragam," Tashwirul Afkar: Jurnal Refleksi Pemikiran Keagamaan \& Kebudayaan 21 (2007): 46-74, 49-55.

${ }^{13}$ Istilah "pemurnian" dipahami dengan menghidupkan kembali rambu-rambu Islam dan menegakkan kembali pilar-pilar Islamiyah agama ini dengan menjaga nash-nash secara bersih dan menghindarkan agama ini dari bid'ah dan penyimpangan yang mengotorinya, baik dalam bidang pemikiran, ibadah maupun perilaku akhlak. Lihat, Agus Hasan Bashari, Mewaspadai
}

Ahmad bin Hanbal, yang menghidupkan ajaran-ajaran salafiyah, sekaligus membuka pintu ijtihad. Ibn Hanbal keras dalam akidah tetapi terbuka dalam ijtihad. Dan karenanya gerakan pemurnian tersebut kemudian bersenyawa dengan spirit ijtihad dan berorientasi kepada upaya membangkitkan kembali umat Islam dari kejumudan dan keterbelakangan. Ibn Taymiyah memandang dunia Islam telah dikotori oleh praktik-praktik tasawuf dan tarekat yang sama sekali tidak berorientasi kepada Sunnah Nabi. Tasawuf dan tarekat yang dimaksud adalah yang mengetengahkan konsep-konsep memuliakan wali secara berlebihan, wasilah dan karamah yang mengandung unsur khurafat dan syirik, seperti kelompok sufi al-Ahmadiyah pada masanya. ${ }^{14}$ Ibn Taymiyah berusaha menghilangkan itu semua dengan menyerukan "kembali kepada tauhid". 15

Gerakan pemurnian Ibn Taymiyah juga menelusup secara bertahap melalui gerakan intelegensia para pengikutnya seperti Ibn Qayyim al-Jauziyah (1292-1350 M.), ${ }^{16} \mathrm{Mu}-$ hammad Ibnu Abdul Hadi (w. 1343 M) ${ }^{17}$ dan Az-Dzahabi (673 - 748 H). Meskipun cukup tertunda, pada gilirannya mempengaruhi gerakan Wahabi yang muncul pada pertengahan abad ke-18 M di Saudi Arabia sebagai gerakan yang paling terorganisir. Pendiri gerakan ini adalah Muhammad bin Abdul Wahab (1703-1792). Tokoh ini pada mulanya adalah penganut sufi yang kemudian menga-

\footnotetext{
Gerakan Konstekstualisasi al-Quran (Surabaya: Pustaka al-Sunnah, 2003), 35.

${ }^{14}$ Ibn Taymiyah, Fatwa-fatwa Ibn Taymiyah, terj. Izzudin Karimi (Jakarta: Pustaka Sahifah, 2008), 23-24.

${ }^{15}$ Nurcholish Madjid, Kaki Langit Peradaban Islam (Jakarta: Paramadina, 1997), 157.

${ }^{16}$ Ibn Qayyim al-Jauziyah dikenal sebagai ulama ahli fikih bermazhab Hambali, ahli tafsir dan hadis sekaligus sebagai mujtahid. Sosok Ibn Qayyim merupakan sosok yang mengusung mazhab salaf. Ibn Qayyim menegaskan tentang bathilnya mazhab taqlid, dan demikian sebagai seorang intelektual ia sering mencetuskan pendapat baru di luar mazhabnya.

${ }^{17}$ Muhammad Ibnu Abdul Hadi (1305-1343) seorang ulama bermazhab Hambali yang hidup di Syam pada masa kekuasaan Mamluk Bahri. Ia merupakan salah satu murid Ibn Taymiyah yang sangat ahli dalam penguasaan fikih, hadis dan ilmu nahwu.
} 
lami semacam konversi agama setelah mendapat pengaruh dari tulisan-tulisan Ibn Taymiyah. Jika Ibn Taymiyah menentang bid'ah, pemujaan kepada para wali dan ziarah ke tempat-tempat suci dan sebagainya, maka Muhammad bin Abdul Wahab dan para pengikutnya justru mencoba mengaplikasikannya dalam tindakan praktis. Lebih dari itu, mereka berekspansi secara militer mulai dari Nejed ke Hijaz sampai ke Mekkah dan Madinah. Muhammad bin Abdul Wahhab benarbenar merekonstruksi pemikiran Ibn Taymiyah dalam bentuk aktivitas yang sangat revolusioner. Hal ini dapat dilihat dari aktivitas dakwahnya. Ia tidak hanya berdakwah lewat gerakan, tetapi juga dibarengi jihad tulisan. Beberapa karya Ibn Abdul Wahab yang dipublikasikan antara lain Kitab Tauhid, Kashf al-Shubhat, Mukhtașar Sirah alNabawiyah, Kitab al-Kabāir, Ușù̀ al-İman dan lain-lain.

Selain gerakan Wahabi di Saudi Arabia, pengaruh Ibn Taymiyah juga menular ke beberapa wilayah lain yang secara politis melahirkan beberapa gerakan-gerakan di berbagai belahan dunia, seperti gerakan Jihad Sakoto di Nigeria, suatu gerakan yang diarsiteki oleh Syaikh Ustman bin Muhammad Fudi (1754 1817) terkenal dengan sebutan Syaikh Usman Don Fodio dan berhasil menciptakan sistem pemerintahan yang didasarkan pada syariat yang kemudian dikenal dengan sebutan Khilafah Sokoto. ${ }^{18}$ Kemudian gerakan Mahdi di Sudan, yakni gerakan yang dipimpin oleh Muhammad bin Abdullah (1834 -1885) dengan tujuan untuk menentang penguasa Ustmani yang tidak memberlakukan syariat, memurnikan keyakinan-keyakinan dan praktik Islam, menggulingkan pemerintahan yang korup dan bid'ah serta menerapkan sistem pemerintahan yang meniru contoh Negara Madinah. Kemudian gerakan Ahl al-Hadis di India, suatu gerakan keagamaan yang dipengaruhi oleh pemikiran Syah Waliyullah. Mereka berpegang pada Alquran dan Sunnah dan tidak mau mengikuti pendapat para ulama dan fuqa-

\footnotetext{
${ }^{18}$ Lihat, Ira M. Lapidus, A History of Islamic Societies, terj. Ghufron A. Mas'adi, Vol.II (Jakarta: Raja Grafindo Persada, 1999), 785-793.
}

ha abad pertengahan bila pendapat tersebut tidak disandarkan pada kedua sumber tersebut, dan lain-lain.

\section{b. Akar Fundamentalisme Modern}

Istilah modern yang digunakan dalam kaitan ini terinspirasi oleh upaya intelektual pada abad ke-18, dan ke-19 sebagai gerakan dengan prototipe revivalis yang oleh Fazlur Rahman $^{19}$ disebut pra-modernis. ${ }^{20}$ Jika setuju dengan pendapat Rahman, maka akar fundamentalisme modern dapat dirujuk berdasarkan perkembangan yang terjadi pada kurun waktu setelahnya, yakni antara abad ke18 sampai abad ke-20. Pada kurun waktu ini kemunculan fundamentalisme sebagai sebuah gerakan dapat dilihat dari beberapa motif, sebagai berikut:

Pertama, Motif Kolonialisme. Sejarah Kolonialisme-Imperialisme yang dimulai pada abad 16 hingga pertengahan abad 20 itulah yang telah merubah peta umat Islam secara drastis. Kolonialisme dengan segala implikasi yang ditimbulkannya -yakni Militerisme, Mercandhise, Missionaris-- secara langsung atau tidak langsung direspon secara berbeda oleh setiap negara jajahan. Bagi para penjajah kegiatan kolonialisme mereka itu dibarengi dengan studi yang intensif dalam skenario besar mereka yang terwujud dalam sebutan "orientalisme"21 Penyelidikan Barat atas

\footnotetext{
${ }^{19}$ Fazlur Rahman, seorang pemikir Islam, lahir di Hazara (Pakistan) pada tahun 1919 dan meninggal pada 26 Juli 1988. Ia mempelajari bahasa Arab di Universitas Punjab dan menempuh pendidikan di Oxford University dengan disertasi tentang Ibn Sina. Beberapa karyanya antara lain Islam (1979), Islam and Modernity (1982), Major Themes of The Quran (diterbitkan oleh Chicago Press tahun 2009), Revival and Reform in Islam (diterbitkan oleh Oneworld Publications tahun 1999), Islamic Methodology in History (1965), dan lain-lain.

${ }^{20}$ Fazlur Rahman, "Root of Islamic NeoFundamentalisme," dalam Change and the Muslim World, ed. Philip H. Stoddard, David C. Cuthell, dan Margareth W. Sullivan (New York: Syracuse University Press, 1981), 27-32.

${ }^{21}$ Kegiatan orientalisme adalah bias cara pandang Barat terhadap Timur (Islam) yang oleh Karel Steenbrink dirinci dalam tiga hal: (i) Prasangka Kristen, (ii) Historisme, dan (iii) Superioritas ras, sehingga para orientalis cenderung melakukan anomali-anomali dalam penyelidikan mereka atas fenomena-fenomena yang
} 
kehidupan sosial budaya masyarakat jajahannya (bangsa Timur) dengan dalih Mission Civilisatrice itu pada gilirannya memunculkan sikap reaksioner dari masyarakat setempat. Munculnya aliran pemikiran kontemporer seperti fundamentalisme, modernisme, messianisme dan tradisonalisme itu diyakini merupakan bentuk lain dari pergumulan dari konfrontasi sosial budaya dengan arus imperialisme Barat. ${ }^{22}$

Kedua, Motif Gerakan Modernisme. Motif lain yang menggerakkan gerakan fundamentalisme adalah munculnya kelompok modernis, ${ }^{23}$ baik yang dimulai oleh Abdul Wahab (1703 - 1787) Muhammad Ali Pasha (1765 1848), Rifa'ah Badawi Rafi' al-Tahtawi (1801 - 1873), Jamaludin al-Afghani (1839 - 1897), Muhammad Abduh (1849 - 1905), Rasyid Ridla (1865 - 1935) dan lain-lain. Menurut Professor Harun Nasution, keseluruhan pembaharu ini mengkritik kondisi umat Islam yang dalam diagnosa mereka peradaban kaum Muslimin sedang terserang penyakit Takhayyul, Bid'ah, Churafat (disingkat TBC). ${ }^{24}$ Muhammad Abduh dan modernis lainnya berusaha menafsir ulang terhadap teks-teks normatif dengan menyesuaikan pada perkembangan dan perubahan-perubahan sosial kemasyarakatan, lebih-lebih dengan penggunaan basis rasional agar diperoleh ajaran-ajaran yang fleksibel dan yang sifatnya adaptatif dengan perkembangan zaman dan peradaban. Menurut H.A.R Gibb, gerakan

terjadi dalam masyarakat muslim. Lihat, M. Amin Abdullah, Studi Agama, Normativitas atau Historisitas (Yogyakarta: Pustaka Pelajar, 1996), 213.

${ }^{22}$ Abdullah, Studi Agama, Normativitas atau Historisitas, 213.

${ }^{23}$ Secara harfiah, modernis adalah keompok yang mendukung atau melakukan sesuatu dalam proses modernisasi. Menurut Fazlurrahman, modernisme Islam yang diperjuangkan oleh kelompok modernis Muslim terletak pada penciptaan ikatan-ikatan positif antara pemikiran Qur'ani dan pemikiran modern mengenai beberapa persoalan kunci yang timbul karena dipadukannya beberapa lembaga modern dengan orientasi alQuran tentang moral dan sosial. Lihat, Stoddard, Cuthell, dan Sullivan, Change and the Muslim World, 31-32.

${ }^{24}$ Harun Nasution, Islam Ditinjau dari Berbagai Aspeknya (Jakarta: UI Press, 1985). h.34 modernisme Islam yang digagas oleh Muhammad Abduh berpengaruh bagi munculnya kelompok konservatisme, tradisonalisme yang kemudian berubah wujud menjadi gerakan fundamentalisme. ${ }^{25}$

Ketiga, Respon Terhadap Euforia Pembaharuan. Euforia pembaharuan yang digalakkan di berbagai dunia Islam dilansir memicu lahirnya fundamentalisme seperti di wilayah Turki Usmani yang dimulai pada masa Sultah Mahmud II (1808 - 1839) dan Sadik Rif'at (1807-1856). Konsentrasi gerakan mengarah pada pemberdayaan ilmu Pengetahuan, ekonomi dan industri. Oleh karena pembaharuan periode ini tidak memuaskan, muncul periode baru dalam Turki modern yakni masa Usmani Muda, yakni Namik Kemal (1840 1888) konsentrasi gerakan pada rekonstruksi Konstitusi Ustmani. ${ }^{26}$

Selain Turki, angin pembaharuan juga berhembus ke India saat Syah Waliyullah al Dahlawiy (1703 - 1762) menyatakan perang terhadap kondisi praktik takhayul dan mistik India yang jauh dari ruh Islam. Gerakan Syah Waliyullah masih dalam taraf idealisme sementara, dan yang mewujudkannya dalam tataran praksis adalah Sayyid Ahmad Syahid $(1752$ - 1831) yang kemudian berlanjut pada kelompok revivalis lainnya seperti Sayyid Ahmad Khan (1817 - 1898), termasuk juga yang semasa dengannya yaitu gerakan Haji Syari'atullah (1817 - 1898). Safari pembaharuan itu kemudian berlanjut di tangan Bapak Pakistan Modern Muhammad Ali Jinah (1876 - 1948) dan tokoh besar lainnya, Muhammad Iqbal (1873 - 1938).

Di tempat lain angin pembaharuan itu juga menerpa Aljazair saat tokoh perhimpunan

\footnotetext{
${ }^{25}$ H.A.R. Gibb, Modern Trends in Islam, terj. Machnun Husein (Jakarta: Raja Grafindo Persada, 1996), 52.

${ }^{26}$ Selanjutnya estafet pembaharuan beralih ke tangan gerakan Turki Muda, di sini ada tiga golongan yang timbul, yakni kelompok yang berorientasi Barat, Nasionalis dan Islamis. Nasionalisme Turki akhirnya menjadi pemenang sebagai dasar pembaharuan modern di bawah kendali Zia Gokalp (1875 - 1924) dan mencapai puncaknya pada masa Musthafa Kemal at Taturk.
} 
Ulama Aljazair, Abu Hamid bin Badis ${ }^{27}$ (1889-1940) menyatakan perang terhadap gerakan tasawuf dan praktik khurafat yang mewabah di wilayah Aljazair. Semua pembaharuan yang mengepung dunia Islam kala itu merangsang sebagian kelompok ummat Islam untuk bersikap reaksioner untuk menyikapi aksi modernis itu. Para pengamat Barat, termasuk Gibb, melihat gerakan reaksioner itu sebagai cikal bakal bagi tumbuhnya gerakan fundamentalisme.

\section{c. Akar Fundamentalisme Post Modern}

Fenomena fundamentalisme post-modern adalah gerakan-gerakan politik (kekuatan bersenjata) untuk melawan hegemoni Barat (baca: Amerika) yang semakin hari semakin kuat mencengkeramkan kuku kekuasaannya ke berbagai wilayah, terutama negara-negara Muslim yang sedang berkembang. Menurut Sayyed Hossein Nasr, bentuk awal gerakan ini ditemukan di Saudi Arabia yang kemudian menjelma dalam berbagai bentuk. Masa tahun 1960-an, terjadi keadaan kekosongan jiwa dan frustasi di Dunia Islam yang disebabkan oleh keinginan untuk menandingi Barat. Keinginan orang banyak adalah umat Islam diizinkan memecahkan masalah-masalah dunia Islam, memelihara agama Islam, memperbaharui syariat, dan membangun kembali kebudayaan Islam. Akan tetapi dominasi kebudayaan Barat sangat menyulitkan keinginan ini. Maka, kemudian didirikanlah organisasi-organisasi Islam untuk mencapai tujuan-tujuan ini dengan cara damai, semisal Ikhwan al-Muslimin di Mesir, dan Jamaat al-Islami di Pakistan. ${ }^{28}$ Termasuk pula didirikannya Hizbuttahrir, Jamah Islamiyah di Mesir, Jamaah Islamiyyah di kawasan Asia Tenggara,

\footnotetext{
${ }^{27}$ Bin Badis lahir dari keluarga pro-Perancis. Terilhami oleh Abduh dan Ridha, pada tahun 1925 ia menerbitkan surat kabar yang berisi gagasan pembaharuan dan pada tahun 1931 mendirikan Perhimpunan Ulama Al-Jazair. Kegiatan dalam organisasi ini memainkan peranan penting dala Arab dalam perkembangan identitas Arab dan Islam di Aljazair. Lihat, H.A.R. Gibb, Modern Trends in Islam, 63-64.

28 Seyyed Hossein Nasr, Pesan-Pesan Universal Islam Untuk Kemanusiaan (Bandung: Mizan, 2003), 127.
}

Gerakan Thaliban di Afghanistan, Gerakan al Qaidah al Islamiyah di Timur Tengah, partai FIS di Aljazair, dan lain-lain.

\section{i. Fenomena Ikhwan Al-Muslimin dan Turunannya}

Pergerakan Ikhwan al-Muslimin (disingkat IM) di Mesir mengalami penindasan oleh rezim penguasa. Seperti ormas-ormas Islam yang lain setelah mendapatkan pengikut dan popularitas, maka IM menjadi organisasi politik hingga terjadilah benturan-benturan dengan penguasa. Pendiri IM Hasan al-Banna akhirnya mati terbunuh. Tak terelakkan lagi, aroma balas dendam pun menyeruak, hingga banyak tokoh-tokoh pemerintah, dari tingkat perdana menteri, anggota kabinet, termasuk lawan politik, dibunuh oleh aktivis kelompok ini. Akhirnya aktivitas politik kelompok ini dilarang oleh rezim penguasa. Meskipun telah dilarang, namun kelompok ini telah memiliki basis yang kuat di masyarakat.

Benturan keras dengan Pemerintah Mesir membawa dampak perpecahan pada kelompok ini: ada yang ingin "berdamai" dengan penguasa, seperti Hasan Hudhaibi, namun ada faksi yang terus memilih konfrontasi dengan penguasa melalui tokohnya Sayyid Quthb yang mengarang buku Ma'ālim Fi al-Taríq (Rambu-rambu Jalan) yang isinya mengafirkan penerapan hukum dan sistem modern serta menyebutkan sebagai jahiliyah abad 20 . Sayyid Quthb yang baru bergabung dengan IM tahun 50-an membawa pengaruh luar biasa terhadap ideologi IM. Sejak saat itu, proses radikalisasi IM yang sebelumnya melalui Hasan Al-Banna agak 'moderat', namun karena pengalaman pribadi Sayyid Quthb yang buruk (dipenjara, disiksa, hingga dihukum gantung), maka ide-ide yang lahir dari Quthb sangat ekstrim.

Ide-ide Qutb sangat berpengaruh pada terbentuknya faksi konfrontatif yang lahir dari perpecahan IM menjadi kelompok-kelompok seperti Tandzimul Jihad, Jamaah Takfir wal Hijrah, dan Jamaah Islamiyah. Lebih jauh lagi, kelompok-kelompok ini juga melakukan perlawanan dengan senjata, terlibat pembunuhan dan kudeta berdarah, mulai dari pembu- 
nuhan terhadap Menteri Wakaf Mesir Muhammad Husein Al-Dzahabi - karena dianggap loyal pada pemerintahan yang kafir hingga puncaknya pada pembunuhan Presiden Mesir Anwar Sadat tahun 80-an.

\section{ii. Jama'at Islami dan Jam'aah Islamiyyah}

Di Pakistan, gelombang fundamentalisme menjelma dalam organisasi Jama'at Islami yang di dirikan Sayyid Abul A'la al Mawdudi ${ }^{29}$ pada tahun 1941. Organisasi ini mencerminkan gerakan ideologi sekalipun tidak bisa meninggalkan kesannya sebagai organisasi dengan basis politik yang kuat. Bagi al-Mawdudi, Islam adalah jalan hidup universal dan komprehensif, sistem yang tertata dengan baik dan konsisten dengan seperangkat jawaban bagi semua persoalan yang dihadapi manusia. Negara Islam dikonsepsikan sebagai bentuk pemerintahan yang Teo-Demokratik, sebuah perpaduam gaya Barat dan Islam yang kental. Pada tahun 1947, ketika dua negara anak benua India itu didirikan (baca: Pakistan dan India), Jama'at Islami terbagi dua, yakni Jama'at al-Islam India dan Jama'at al-Islam Pakistan. Dalam perjuangannya, Al-Mawdudi memusatkan perhatian pada pendirian suatu negara Islam dan masyarakat Islam yang sebenarnya di negeri tersebut.

Secara penamaan, organisasi Jama'at Islami yang didirikan Al-Mawdudî ini berbeda dengan Jama'ah Islamiyah (disingkat $\mathrm{JI}$ ),

\footnotetext{
${ }^{29}$ Karir Sayyed Abu A'la al-Mawdudi dimulai dari jurnalis, editor surat kabar Taj, kemudian Pemred surat kabar Muslim (1921-1923), surat kabar Aljam'iyat (1925-1928), dua surat kabar yang diterbitkan oleh Jam'iyat al- Ulama al-Hind, (baca: organisasi ulamaulama muslim India).

${ }^{30}$ Salah satu konsep untuk memahami fenomena fundamentalisme Jama'ah Islamiyah (JI) adalah dengan memposisikannya sebagai bagian dari gerakan sosial (social movement). Fokus konsep ini bertitik tolak dari paradigma gerakan sosial lama (old social movement paradigm) yang tidak menyertakan agama sebagai satusatunya faktor pendorong konflik, melainkan juga kelas (class) sebagai faktor utama munculnya gerakan sosial. Cara pemahaman seperti inilah yang kemudian disebut dengan class interpretation. Untuk melihat gerakan fundamentalisme JI, juga dapat dilihat dari teori perlawanan (oppositionalism) atau teori perjuangan
}

yakni organisasi yang dibentuk oleh Abdullah Sungkar di Malaysia pada 1994 atau 1995. Yang disebut terakhir ini tidak untuk dirancukan dengan istilah umum "Jama'ah Islamiyah" yang artinya "komunitas Islami", ataupun "Jamaah Islamiyyah" yang berdiri di Mesir. Sebab, organisasi JI resmi masuk dalam organisasi teroris di PBB pada 23 Oktober 2002. JI memiliki jaringan pendukung di seluruh Indonesia, Malaysia, Singapura dan Filipina Selatan. JI juga diduga telah mengadakan kontak dengan organisasi Muslim di Thailand dan Burma. Pun negara kaya minyak Brunei boleh jadi sudah diliriknya sebagai sumber dukungan atau tempat pelarian. ${ }^{3}$

Melihat luasnya jaringan JI seperti itu, maka pertemuan antara kecenderungan radikalisme (baca: terorisme internasional dan domestik), menurut Bruce Hoffman, ${ }^{32}$ meru-

(fight) yang melihat fundamentalisme dari lima ciri perlawanan. Pertama, fight back, yakni perlawanan dilakukan terhadap kelompok yang mengancam keberadaan atau identitas yang menjadi taruhan hidupnya. Kedua, figh for, yakni berjuang untuk menegakkan cita-cita yang mencakup persoalan hidup secara umum, seperti keluarga dan istitusi lainnya. Ketiga, fight with, yakni berjuang dengan kerangka nilai yang diambil dari warisan masa lalu maupun konstruksi baru. Keempat, faight against, yakni berjuang melawan musuh-musuh tertentu yang muncul dalam bentuk komunitas atau tata sosial keagamaan yang dipandang menyimpang. Kelima, fight under, yakni berjuang atas nama Tuhan atau ide-ide yang lain.

${ }^{31}$ Organisasi JI tersebut merupakan jelmaan sebuah hibrida ideologi. Ada pengaruh kuat dari kelompok Islam radikal di Mesir, dalam arti struktur organisasi, kerahasiaan, dan misi jihadnya. Gerakan Darul Islam pada yang didirikan tahun 1950an masih tetap menjadi ilham yang kuat, akan tetapi ada warna anti-Kristen yang menonjol pada ajaran-ajaran JI yang bukan ciri Darul Islam.

${ }^{32}$ Bruce Hoffman adalah Direktur CPSS (Center for Peace and Security Studies) di Georgetown University's dan spesialis pengkaji masalah terrorism. Ia juga menjadi Director of the RAND Corporation's Washington Office (1998-2006), Vice President for External Affairs at RAND (2001-2004) and held the RAND Corporate Chair in Counterterrorism and Counterinsurgency (2006-2006). Beberapa buku yang dipublikasikan Hoffman's antara lain Inside Terrorism (1998; 2nd expanded and revised edition 2006); and, The Failure of Britain's Military Strategy in Palestine, 1939-1947 (1983). Ia juga menjadi editor-in-chief of the 
pakan alasan yang mendorong pertumbuhan teroris sangat variatif dan komplek. Di samping faktor secara umum adalah; termotivasi oleh bentuk perintah agama, meningkatnya kemampuan dan wewenang teroris itu sendiri ikut mendorong pada bentuk professional. Terorisme karena motivasi agama lebih besar volumenya daripada motivasi etnis, nasionalisme, sparatisme ataupun idiologi.

\section{iii. Hizbut Tahrir}

Di era tahun 20-an Dinasti Utsmaniyah di Turki runtuh, dan yang diganti dengan sistem negara sekuler oleh Mustafa Kemal Attaturk. Runtuhnya Dinasti ini membawa trauma dan diratapi oleh seorang hakim agama yang menjadi pegawai resmi Dinasti Utsmaniyah di Palestina, bernama Taqiyuddin Al-Nabhani. Bagi Al-Nabhani Dinasti Utsmaniyah adalah Khilafah Islam, dan keruntuhannya merupakan keruntuhan sistem politik Islam. Untuk itulah, ia bermimpi menegakkan kembali Khilafah Islam itu dengan membangun sebuah gerakan politik internasional yang bertujuan mendirikan kembali kekhalifahan Islam diberi nama Hizb Tahrir. Hizb Tahrir ini mengharamkan demokrasi, nasionalisme, pemilu, batas-batas teritorial negara, dan lain-lain, yang dalam pandangannya bertentangan dengan hukum Islam. Meskipun negara-negara berpenduduk mayoritas muslim di dunia mempraktikkan konsep "negara-bangsa" yang dituding konsep kufur oleh Hizb Tahrir .

Karena di negerinya sendiri tidak bisa berkembang, sementara di negara-negara Arab dikejar-kejar oleh rezim penguasa, kelompok ini "lari" dari medan perang, dan membangun organisasinya di sebuah negara sekuler-yang seluruh prinsip, dasar, undang-undangnya diharamkan-yakni Inggris. Hizb Tahrir hidup dan kuat di negeri yang pernah menjanjikan wilayah untuk Zionisme. Dengan kata lain, gerakan ini hanya bisa hidup dan berkembang

scholarly journal, Studies in Conflict and Terrorism; and, the series editor of Columbia Studies in Terrorism and Irregular Warfare, published by Columbia University Press. di negara Demokrasi, suatu sistem negara yang menjadi lahan kritik kerasnya.

\section{Tipologi Fundamentalisme: Pragmatis, Radikal dan Idealis}

Setelah menelusuri akar dan motif kemunculan fundamentalisme, penulis terpanggil (involed) untuk membuat tipologi fundamentalisme serta prospeknya di Nusantara. Tipologi penting dibuat untuk memetakan potensi, kekuatan, orientasi dan realitas pergerakannya. Secara sederhana gerakan fundamentalisme yang masuk dan berkembang di Nusantara dapat diklasifikasikan menjadi tiga varian besar, sebagai berikut.

Pertama, Kelompok fundamentalisme yang lahir dari ketegangan, perebutan kekuasaan, hingga konflik yang ada di Timur Tengah. Kita akan menjumpai geneologi, akar-akar, dan sebab-musabab munculnya kelompokkelompok itu di beberapa kelompok di Timur Tengah. Dalam konteks ini gerakan fundamentalisme yang muncul dan berkembang di Nusantara terkait erat dengan situasi politik dan bahkan konflik yang tak pernah surut di Timur Tengah. Maka, persoalan konfrontasi dengan Israel untuk membela hak-hak kemanusiaan warga Palestina, misalnya, tetap menjadi komoditas politik paling seksi untuk dikemas.

Untuk mendudukkan tipologi ini, kita lihat kembali pengalaman Ikhwan al-Muslinin (IM) di Mesir yang pecah menjadi dua faksi, yakni yang "pragmatis" dan "konfrontatif" terulang di Indonesia. Jubah baru kelompok ini di tanah air muncul dalam gerakan fundamentalisme DI/TII atau NII (sebutan untuk Negara Islam Indonesia). Gerakan DI/TII dan NII merupakan gerakan bawah tanah yang tak pernah pupus. Sejarah mencatat keberadaan DI/TII pertama kali diproklamirkan oleh Sekarmaji Marijan Kartosuwiryo pada 7 Agustus 1949 dengan basis gerakan di daerah Tasikmalaya, Jawa Barat. Gerakan serupa kemudian meluas di Sulawesi Selatan dengan di pimpin Kahar Muzakar pada 20 Januari 1952. Kemudian 
disusul pembentukan NII di Aceh oleh Abu Daud Beureuh pada 21 September 1953. ${ }^{33}$

Realitasnya kelompok yang didirikan oleh Kartosuwiryo DI/TII ini gagal melakukan konfrontasi bersenjata. Kegagalan ini membelah tubuh DI/TII menjadi dua, pertama, faksi yang mulai "pragmatis" memilih perlawanan tak langsung, dengan membangun gerakan-gerakan dakwah di kampus-kampus, yang dikenal sebagai kelompok-kelompok Usroh dan lembaga dakwah kampus (LDK). Pengkaderannya mengambil model IM di Mesir, dan memopulerkan buku-buku Hasan al-Banna dan Yusuf al-Qaradlawi (tokoh IM yang 'pragmatis').

Kemudian karena tokoh-tokoh IM Mesir mendapat simpati dan bantuan penuh dari Dinasti Saudi (mereka dirangkul karena menjadi musuh rezim nasionalis Arab yang sekuler, musuh utama Dinasti Saudi juga), maka gerakan-gerakan dakwah kampus di Indonesia pun mendapat dukungan dana dari DDII. Pada Reformasi 1998 kelompok ini mendeklarasikan satu partai, yakni Partai Keadilan dan sekarang menjadi Partai Keadilan Sejahtera (PKS).

Kedua, Kelompok fundamentalisme dengan ciri khas tertutup, merasa benar sendiri, gemar mengafirkan, tidak mengakui keanekaraman, dan menuntut penyeragaman. Dan yang lebih gawat lagi mereka menganjurkan hingga melakukan tindakan kekerasan. Sikap fanatisme dan "mengafirkan", menurut Syekh Nagih Ibrahim, seorang tokoh Jama'ah Islamiyyah (JI) di Mesir yang telah "bertaubat" disebut sebagai "terorisme pemikiran" yang lebih berbahaya dari "terorisme fisik" (innal irhāb al-fikri ashaddu takhwifan wa tahdidan minal irhāb al-hissī).

Penulis melihat kelompok ini sebagai faksi lain IM yang memilih jalur "konfrontasi radikal" dan kemudian tumbuh dan berkembang dengan mengambil pola pengkaderan ala Jamaah Islamiyah (JI) Mesir. Wajah mereka di Nusantara nampak karena jejak radikalisme

\footnotetext{
${ }^{33}$ Luqman bin Muhammad Ba'abduh, Mereka Adalah Teroris: Bantahan terhadap Buku Aku Melawan Teroris karya Imam Samudra (Malang: Pustaka Qaulan Sadida, 2005).
}

tetap digemborkan. Mereka memopulerkan buku-buku Sayyid Qutb dan Abdus Salam Faraj al-Farìdah al-Ghā'ibah (Kewajiban yang Hilang) buku yang mematok perang sebagai jihad. Faksi ini pun bermetaformosis menjadi Jamaah Islamiyah $(\mathrm{JI})^{34}$ di Indonesia yang didirikan oleh Abdullah Sungkar ${ }^{35}$ dan Abu Bakar Ba'asyir, hingga berdirinya Majlis Mujahidin Indonesia (MMI) tahun 2000. ${ }^{36}$

Perpecahan kian memburuk ketika Ba'asyir bersama Irfan Suryahardi Awwas dan Mursalin Dahlan, yang merupakans aktivis Muslim dan mantan tahanan politik, mendirikan Majelis Mujahidin Indonesia (MMI) pada 7 Agustus 2000. ${ }^{37}$ Menurut kaum radikal,

\footnotetext{
${ }^{34}$ Realitas gerakan fundamentalisme (baca: radikalisme) dapat dilihat dari beberapa rentetan serangan, seperti serangan 12 Oktober 2002 di Bali yang menewaskan hampir 200 orang yang diduga dilakukan Jama'ah Islamiyah (JI) dan beberapa serangan lainnya.

${ }^{35}$ Ajaran Sungkar disebarkan tidak saja melalui JI tetapi juga pada pesantren yang turut didirikannya di Malaysia bernama Pondok Pesantren Luqmanul Hakiem di Johor. Ketika Abdullah Sungkar wafat pada November 1999, Ba'asyir menggantikannya sebagai ketua JI. Akan tetapi banyak anak buah Sungkar yang direkrut di Indonesia, terutama kaum pemuda yang lebih militan, sangat tidak puas dengan peralihan kepemimpinan ke tangan Ba'asyir. Kelompok yang lebih muda tersebut di antaranya termasuk Riduan Isamuddin alias Hambali; Abdul Aziz alias Imam Samudra, yang ditangkap di Jawa Barat pada 21 November 2002; Ali Gufron alias Muchlas (kakak Amrozi, seorang pelaku kunci dalam kasus bom Bali, yang tertangkap pada 3 December); dan Abdullah Anshori, alias Abu Fatih. Mereka menganggap Ba'asyir terlalu lemah, terlalu bersikap akomodatif, serta terlalu mudah dipengaruhi orang lain. Menurut Magnus Rastorp, di sini terlihat betapa pentingnya peran dari pemimpin rohani dalam organisasi ini, sebagaimana ditunjukkan oleh peran Syekh Umar Abdurrahman Mesir dalam fatwanya untuk membantai Anwar Sadat dan memusuhi orang Barat yang berada di Mesir.

${ }^{36}$ Kongres Pertama MMI mengusung 4 target, (i) Memadukan visi dan misi perjuangan para Mujahidin dalam menegakkan syariat, (ii) Membangun shaf Mujahidin yang kokoh dan kuat, regional maupun internasional, (iii) Terbentuknya institusi Mujahidin, (iv) Mewujudkan Dewan Kepemimpinan Umat sebagai Khalifah fil Ardhi. Lihat, Irfan Suryahardi Awwas, Risalah Kongres Mujahidin I Dan Penegakan Syariat Islam (Yogyakarta: Wihdah Press, 2001), xxvi.

${ }^{37}$ Deklarasi MMI di Jogjakarta dihadiri oleh 1800 orang peserta dengan tema mengusung tema "Kongres
} 
konsep MMI telah menyimpang dari ajaranajaran Abdullah Sungkar. Misalnya, mereka menganggap hal itu merupakan pengkhianatan terhadap ijtihad politik Sungkar agar JI tetap bekerja di bawah tanah hingga muncul saat yang tepat untuk menegakkan negara Islam. Tapi, Abu Bakar Ba'asyir berdalih bahwa keterbukaan yang terjadi pasca Soeharto membuka peluang-peluang baru; jika peluang tersebut tidak diraih, maka hal itu bukan saja langkah yang salah, bahkan sebuah dosa. Terakhir, Abu Bakar Ba'asyir ditendang dari MMI (dituding mirip Syiah, Ahmadiyah dan komunis) dan mendirikan kelompok Ansharut Tawhid.

Ketiga, Kelompok fundamentalisme lain yang cukup berpengaruh di ranah Nusantara adalah kelompok Hizbut Tahrir Indonesia (Partai Pembebasan Indonesia, disingkat HTI) yang mengusung idealisme khilafah sebagai gerakan Islam bercorak transnasional. Meski tidak begitu jelas orientasinya, hingga datangnya Syaikh Taqiyuddin al-Nabhani tahun 1972 ke Indonesia, ${ }^{38}$ kelompok ini ingin meneruskan cita-cita Pan-Islamisme untuk mengembalikan supremasi Islam pada abad pertengahan dalam bentuk mendirikan Khilafah Islamiyah. Terkait dengan ini ada dua isu sentral yang diusung oleh Hizbut Tahrir, termasuk HTI, yaitu Khilafah Islamiyyah dan Syariat Islam, sebagai wujud dari sistem yang diyakini, dipahami dan dipraktekkan dalam kehidupan.

Pilihan Idealis "Khilafah" sebagai satusatunya bentuk pemerintahan yang diyakini dapat mewujudkan kemakmuran dan kedamaian adalah sabda Nabi Saw. Yang terjemahannya sebagai berikut, "Bani Israil, yang mengatur urusan mereka adalah para Nabi. Setiap kali meninggal seorang Nabi, maka digantikan oleh Nabi yang lain, dan bahwasanya tidak ada Nabi sesudahku, dan

\footnotetext{
Mujahidin I Indonesia untuk Penegakan Syariat Islam”. Lihat, Haedar Nashir, Gerakan Islam Syariat: Reproduksi Salafiyyah Ideologis di Indonesia (Jakarta: PSAP, 2007), 392.

38 Lihat, A. Maftuh Abegebriel, A. Yani Abeveiro, dan SR-Ins Team, Negara Tuhan: The Thematic Ensyclopedia (Jakarta: SR-Ins Publishing, 2004), 694.
}

akan ada para Khulafa, dan kemudian akan banyak sekali (jumlahnya). ${ }^{39}$

\section{SIMPULAN}

Bagian akhir dari tulisan ini melihat prospek fundamentalisme di Indonesia. Bagaimana prospek fundamentalisme di tanah air? Untuk menjawab pertanyaan ini kita mesti melihat motif lain yang tak kalah pentingnya yang mendorong munculnya gerakan-gerakan ini, sebagai berikut.

Pertama, Bahwa situasi politik, ekonomi, budaya dan keamanan di Nusantara dari waktu ke waktu tak kunjung memperlihatkan kondisi yang dinamis, baik masa Orde Baru yang diakhiri dengan tumbangnya rezim Soeharto, masa reformasi dan era kekinian yang disinyalir masih menyisakan pertanyaan besar bagi akurasi ideologi dalam mewujudkan keadilan dan kesejahteraan di masyarakat. Kenyataan ini diyakini memberi ruang gerak yang leluasa bagi tumbuh dan berkembangnya gerakan fundamentalisme di tanah air.

Kedua, Bahwa fakta negara tak kunjung berhasil mewujudkan kesejahteraan dan keadilan dalam berbagai bidang dengan sistem yang dianutnya, menjadi faktor dominan bagi masyarakat untuk mencari alternatif prinsip dan ideologi pembangunan yang diharapkan dapat mewujudkan kesejahteraan dan keadilan. Atas dasar ini, kiranya fundamentalisme Islam (bukan radikalisme) tidak perlu disikapi secara apriori apalagi phobia, akan tetapi ditempatkan dalam kerangka kekayaan khazanah bangsa yang multi kultural.

Ketiga, Meskipun fundamentalisme Islam selalu diasosiasikan dengan kelompok radikal, sebenarnya hanya beberapa varian kecil saja yang nyata-nyata memperlihatkan sifat dan sikap radikal. Sekali lagi fundamentalisme masih dapat diakomodir sebagai kekayaan bangsa dengan menafikan gerakan-gerakan yang menjadi parasit di dalamnya. Jadi rumusannya adalah fundamentalisme yes, radikalisme no!! Wallahu A'lam.

\footnotetext{
${ }^{39}$ Hadis Riwayat Muslim dan Abi Hazim
} 


\section{DAFTAR PUSTAKA}

Abdullah, M. Amin. Studi Agama, Normativitas atau Historisitas.

Yogyakarta: Pustaka Pelajar, 1996.

Abegebriel, A. Maftuh, A. Yani Abeveiro, dan SR-Ins Team. Negara Tuhan: The Thematic Ensyclopedia. Jakarta: SR-Ins Publishing, 2004.

Al-Faruqi, Ismail Rajie. "Islamic Renaissance in Contemporary Society." Al Ittihad 15, no. 4 (1978): 15-23.

Ali Mudhofir. Kamus Teori dan Aliran Dalam Filsafat dan Teologi. Yogyakarta: Gajahmada University Press, 1996.

Armstrong, Karen. Berperang Demi Tuhan. Bandung: Mizan, 2013.

Awwas, Irfan Suryahardi. Risalah Kongres Mujahidin I Dan Penegakan Syariat Islam. Yogyakarta: Wihdah Press, 2001.

Bashari, Agus Hasan. Mewaspadai Gerakan Konstekstualisasi al-Quran. Surabaya: Pustaka al-Sunnah, 2003.

Bruce, Steve.

Fundamentalisme. Diterjemahkan oleh Herbhayu Noerlambang. Jakarta: Erlangga, 2000.

Emarah, Muhammad. Fundamentalisme Dalam Perspektif Pemikiran Barat dan Islam. Jakarta: Gema Insani Press, 1990.

Gibb, H.A.B, dan J.H. Kramers. Shorter Encyclopedia of Islam. Leiden: E.J. Brill, 1974.

H.A.R. Gibb. Modern Trends in Islam. Diterjemahkan oleh Machnun Husein. Jakarta: Raja Grafindo Persada, 1996.

Hofmann, Murad W. Menengok Kembali Islam Kita. Diterjemahkan oleh Rahmani Astuti. Bandung: Pustaka Hidayah, 2002.
Lapidus, Ira M. A History of Islamic Societies. Diterjemahkan oleh Ghufron A. Mas'adi. Vol.II. Jakarta: Raja Grafindo Persada, 1999.

Luqman bin Muhammad Ba'abduh. Mereka Adalah Teroris: Bantahan terhadap Buku Aku Melawan Teroris karya Imam Samudra. Malang: Pustaka Qaulan Sadida, 2005

Madjid, Nurcholish. Kaki Langit Peradaban Islam. Jakarta: Paramadina, 1997.

Nashir, Haedar. Gerakan Islam Syariat: Reproduksi Salafiyyah Ideologis di Indonesia. Jakarta: PSAP, 2007.

Nasr, Seyyed Hossein. Pesan-Pesan Universal Islam Untuk Kemanusiaan. Bandung: Mizan, 2003.

Nasution, Harun. Islam Ditinjau dari Berbagai Aspeknya. Jakarta: UI Press, 1985.

. Islam Rasional. Bandung: Mizan, 2000.

Qardhawi, Yusuf. Masa Depan Fundamentalisme Islam. Jakarta: Pustaka Al-Kautsar, 1997.

Qodim, Husnul. "Dinamika Salafisme di Indonesia: Akar Intelektualitas dan Orientasi Ideologis yang Beragam." Tashwirul Afkar: Jurnal Refleksi Pemikiran Keagamaan \& Kebudayaan 21 (2007): 46-74.

Stoddard, Philip H., David C. Cuthell, dan Margareth W. Sullivan, eds. Change and the Muslim World. New York: Syracuse University Press, 1981.

Taymiyah, Ibn. Fatwa-fatwa Ibn Taymiyah. Diterjemahkan oleh Izzudin Karimi. Jakarta: Pustaka Sahifah, 2008. 